\title{
Glucose-Induced Degradation Protein 4 Homolog
}

National Cancer Institute

\section{Source}

National Cancer Institute. Glucose-Induced Degradation Protein 4 Homolog. NCI

Thesaurus. Code C147974.

Glucose-induced degradation protein 4 homolog (300 aa, $34 \mathrm{kDa}$ ) is encoded by the human GID4 gene. This protein plays a role in the ubiquitination and proteasomal targeting of gluconeogenic enzymes. 